ARTICLE

\title{
Limitations of the institutional development plan of the Higher Education Federal Institutes in Brazil
}

\author{
Alexandre Nascimento de Almeida a \\ Anderson Allan Almeida Galvão ${ }^{b}$
}

\section{Abstract}

The Federal Institutes (FI) are specialized in technical and technological vocational education at different levels and modalities. The instrument for planning and evaluation in higher education institutions in Brazil is the Institutional Development Plan (IDP) and the objective of this paper is to evaluate the limitations of the IDP for FI. To do so, the application of a questionnaire to the managers of the FI was carried out and information that addressed the limitations of the IDP was obtained. The main limitations were related to the political and institutional aspects of the FI, demonstrated by the concern of their managers with the lack of knowledge of the community about the institution itself.

Keywords: Planning. Management. Higher Education.

\section{Introduction}

The Higher Education Institutions (HEI) in Brazil comprise the Higher Education Federal Institutes (FI) and the universities, including two Federal Technological Education Centers (FTEC) and technical schools linked to universities. Unlike universities, FI specialize in the provision of professional and technological Education at different levels and modalities of teaching.

The first public policy for the evaluation of Higher Education in Brazil took place in 1993 through the Institutional Evaluation Program of Brazilian Universities (IEPBU) (ALMEIDA JUNIOR, 2004). Two years later, the National Examination of Courses was created, promulgated by Law No 9,131/1995 (BRASIL, 1995). In 2004, through Law $N^{\circ} 10,861 / 2004$, the National Higher Education Assessment

\footnotetext{
a Faculdade UnB de Planaltina, Universidade de Brasília, Brasília, DF, Brazil.

b Instituto Federal de Brasília, Brasília, DF, Brazil. 
System (NHEAS) was instituted, establishing the Institutional Development Plan (IDP) as an instrument for planning and evaluating HEI (BRAZIL, 2004).

According to Moraes and Kalnin (2018), the determination of the effectiveness of this evaluation requires reflection on the meaning of the term "quality", since it is important to know what is actually intended with the implementation of an Education policy. In the same way, for Frangella and Mendes (2018, p. 297): "quality becomes an ambiguous term with differentiated functions within the same discursive system, used in a strategic political arrangement".

In the last decade, there has been a strong expansion of Higher Education in Brazil, with universities doubling their vacancy numbers and FI assuming unpredicted proportions, increasing their number of vacancies offered by $236 \%$ between 2008 and 2017 (INEP, 2019). This rapid expansion has raised doubts as to the quality of the Education offered, with habitual criticisms regarding the unplanned creation of courses, often unattractive and unrelated to the socioeconomic reality of each region, raising the importance of planning and evaluation of HEI in Brazil (BISINOTO; ALMEIDA, 2017; BRITO, 2013).

Although the IDP is the document for the planning and evaluation of all HEI in Brazil, it presents limitations for FI given the differences between these institutions and the universities, each of which lacking in different evaluation criteria. Furthermore, unlike universities, the FI are recent institutions created under Law $\mathrm{N}^{\mathrm{o}} 11,892$ of 2008 (BRAZIL, 2008), and are in the process of consolidating their role. These factors make it even more difficult to determine the parameters for the planning and evaluation of FI and justify the evaluation of the IDP as a universal planning tool for higher education.

Thus, the objective of this work is to evaluate the limitations of the IDP as a tool for planning the FI from the perception of their managers and then propose adjustments in the construction and monitoring of this instrument.

\section{Theoretical reference}

\subsection{Planning and Management in Higher Education Institutions}

Initially, strategic planning was restricted to analyzing the strengths and weaknesses of an organization, but then it expanded afterwards, presenting concerns about planning and management changes in the organizational environment (FALSARELLA; JANUNUZZI, 2017). 
Fischmann and Almeida (2009) stated that strategic planning can be defined as an administrative technique that, based on the analysis of an organization's environment, identifies its opportunities and threats, its strengths and weaknesses, and in tune with its mission, creates a direction to be followed in pursuit of its goals.

According to Cunha (1995), public institutions, because they are created and sustained by the public power, generally have guaranteed survival and, therefore, do not raise much alarm to concerns about threats and opportunities. At the same time, these institutions face great difficulties to define and operationalize their objectives, plus they lack the managerial ability to establish rapid changes.

Andriola and Araújo (2018) highlighted the importance of the use of indicators for the Higher Education management, pointing out that a limited but significant selection of indicators allows a summary idea of the functioning of a given reality, contributing to decision making in Higher Education Institutions.

In this perspective, Colombo (2004) evaluates that strategic planning is an important management tool and that considerably assists the educational administrator in his decision-making processes in search of more effective and competitive results for educational institutions. Sá (2018) addressed some of the rationalities that make up the educational evaluation, presenting arguments between emancipation and promotion of actors' reflexivity on one side and control on the other.

In this way, it is understood that strategic planning is based on defining the objectives and goals of the organization and where to direct its resources to achieve them. Planning enables the organization to optimize time, resources, costs and benefits in achieving objectives (ATHANÁZIO, 2010).

For Costábile (2007) the process of strategic planning consists of defining the objectives to be accomplished, the activities that must be performed and the resources that must be used, so that all the purposes of an institution are actually achieved.

However, to achieve the planned objectives, management needs to be effective. In this regard, Silva (2008) affirms that the effective management of an HEI is very complex and that the value creation for students, teachers, employees and society is based on the balanced management of intangible assets (knowledge, processes, systems and information) and in the planning and control of the financial resources that will translate into the provision of educational services and the perpetuity of the institution. 


\subsection{The Institutional Development Plan (IDP)}

The IDP is a document that contains an essential part of HEI strategic planning. The IDP needs to consider public policies, institutional needs and community demands. Its minimum composition is established by Decree $\mathrm{N}^{\circ}$ 9,235/2017 (BRAZIL, 2017), which serves as a guide for the basis of institutional planning. This document guides the institutional and course evaluation, as well as the directions that the HEI need to follow.

The IDP consists of a document that defines the mission and the strategies to achieve the goals and objectives of HEI. The document covers a period of five years and must have a schedule and methodology for the implementation of the action plan, observing the coherence and articulation between the various actions, the maintenance of quality standards and, when appropriate, the institution's budget. It should present a summary table containing the list of the main performance indicators, which makes it possible to compare, for each one, the current and future situation, that is, after the validity of the IDP.

The IDP must be closely articulated with the practice and results of the institutional evaluation, carried out both as a self-evaluation procedure and in external evaluations. The results of these assessments should identify actions to address deficiencies that have been identified.

Although mandatory, the Ministry of Education allowed the free construction of the IDP, guaranteeing the HEI the exercise of their creativity and freedoms in the process of elaborating their development plan. However, by law, the document must be aligned with the 10 dimensions foreseen in Sistema Nacional de Avaliação da Educação Superior (Sinaes): 1) mission of the institution; 2) policies for teaching, research and extension; 3) social responsibility; 4) communication with society; 5) personnel policies; 6) organization and management of the institution; 7) physical infrastructure; 8) planning and evaluation; 9) student service policies; 10) financial sustainability.

\section{Methodology}

\subsection{Collecting Data}

The IDP bottlenecks were identified through the perception of FI managers. To do so, an electronic questionnaire was sent containing four open questions with the intention of analyzing the limitations of the IDP, considering the following aspects: 1) social and cultural, 2) political and institutional, 3) legal and administrative, and 4) pedagogical and methodological (Chart 1). 
Chart 1 - Questionnaire applied to managers of FI to assess IDP limitations.

I. IDP LIMITATIONS (Inform in the fields below, in the form of topics, limitations or possibilities for improvement to enhance the use of IDP as a management tool.)

1. Social and cultural aspects (It is understood as social aspects those related to social inequality, ethnicity, gender, generation, sexual orientation, creed, etc. Cultural aspects are understood as those related to practices, symbols, values, behaviors, habits, beliefs, principles, among others.)

2. Political and institutional aspects (These are understood as political aspects related to interinstitutional relations, governmental relations, partnerships, as well as democratic practices, transparency, publicity, etc. Institutional aspects are understood as tradition, mission, vision, values, objectives, purpose of the institution, among others.)

3. Legal and administrative aspects (It is understood as legal aspects those that refer to the norms, regulations, regiments, current legislation and correlates. Administrative aspects are those that refer to planning, finances, budget, organizational structure, planning, human resources, among others.)

4. Pedagogical and methodological aspects (It is understood as pedagogical aspects those related to the type of teaching, evaluation, content, course structure, institutional political project, among others. Methodological aspects are understood as those related to the definition of space and time of the course. Teaching methods, training and qualification of educators, among others).

Source: Prepared by the authors (2017)

The questionnaire was applied between December 2015 and February 2016. The questionnaire was sent by e-mail to 7,408 managers who act in managing positions in FI throughout Brazil and, therefore, deal directly or indirectly with planning in the institutions in which they work. The identification of these public servants that work in management positions was obtained from public information available in the transparency portal (BRAZIL, 2014).

The sample obtained had 97 questionnaires fully answered, representing managers of 21 institutions of the country. Some factors that hindered the expansion of the sample were: the lack of standardization of e-mails in FI; direct mail blocked by AntiSpam tools in e-mail public servants of some institutions (is a tool usually employed by providers, which is intended to help users avoid unwanted messages such as product advertisements or websites and "chains", among others); the optional feature of completing the questionnaire; the application of the questionnaire coincides with the recess and holiday period of the managers.

\subsection{Analyzing Data}

In order to analyze the data, especially the information from the open questions of the questionnaire, the Content Analysis technique was used. For Bardin (2011, p. 45), Content Analysis can be understood as: 
[...] a set of communication analysis techniques aimed at obtaining, by systematic and objective procedures for describing the content of the messages, indicators (quantitative or otherwise) that allow the inference of knowledge regarding production/reception conditions (inferred variables) of these messages (BARDIN, 2011, p. 45).

The stages of the Content Analysis technique are: 1) pre-analysis, 2) exploration of the material, and 3) interpretation of the results.

The pre-analysis comprised of a float reading of all the answers obtained. Then, in the exploration of the material, the answers were classified according to the 10 evaluation dimensions proposed by Sinaes: 1) mission of the institution; 2) policies for teaching, research and extension; 3) social responsibility; 4) communication with society; 5) personnel policies; 6) organization and management of the institution; 7) physical infrastructure; 8) planning and evaluation; 9) student service policies; 10) financial sustainability, in order to achieve a more detailed analysis of the data as recommended by Missio, Alves and Hildenbrand (2018).

The interpretation of the results was done by calculating the frequency of responses within each dimension proposed by Sinaes, allowing to verify which category presented the highest number of criticisms or suggestions.

\section{Results and discussions}

\subsection{Identification of the IDP limitations for FI}

Table 1 presented the total answers within the four questions in the questionnaire. The political and administrative aspect amounted to 113 contributions, which corresponded to $45 \%$ of the total opinions. The aspects: pedagogical and methodological, legal and administrative, social and cultural obtained several contributions, each with approximately 45 contributions or $20 \%$ of the total responses.

Table 1 - Answer categorization distributed in the four analyzed aspects

\begin{tabular}{lcc}
\hline Aspects analyzed & Quantity & Percentage \\
\hline Social and cultural & 44 & $17 \%$ \\
Political and institutional & 113 & $45 \%$ \\
Legal and administrative & 45 & $18 \%$ \\
Pedagogical and methodological & 49 & $20 \%$ \\
\hline Total answers & 251 & $100 \%$ \\
\hline
\end{tabular}

Source: Prepared by the authors (2017) 
Immediately, there is a considerable difference between the amount of criticism or suggestions for the political and institutional aspect of the IDP when compared to the other aspects. In general, these criticisms have addressed problems in communication between FI and society, as well as the urgency to revise institutional planning so that it reflects the reality and needs of the community.

\subsection{Political and institutional aspects}

Political aspects include those related to interinstitutional relations, governmental relations, partnerships with other institutions, as well as democratic practices, transparency, publicity, among others. Institutional relations, however, represent aspects such as tradition, mission, vision, values, goals, purpose of the institution, among others.

Figure 1 presented the aggregated answers regarding the political and institutional aspects within the 10 dimensions proposed by Sinaes. Limitations or suggestions were focused on three dimensions, with emphasis on dimension $\mathrm{n}^{\circ} 4$ "Communication with society", with 67 opinions or $59 \%$ of the total responses, followed by dimension $n^{\circ} 8$ "Planning and evaluation", with 31 opinions or $28 \%$ of the total responses and, to a lesser extent, dimension $\mathrm{n}^{\circ} 1$ "Institutional Mission", with 15 opinions or $13 \%$ of the total responses.

Figure 1 - Perceptions of managers about the political and institutional aspects

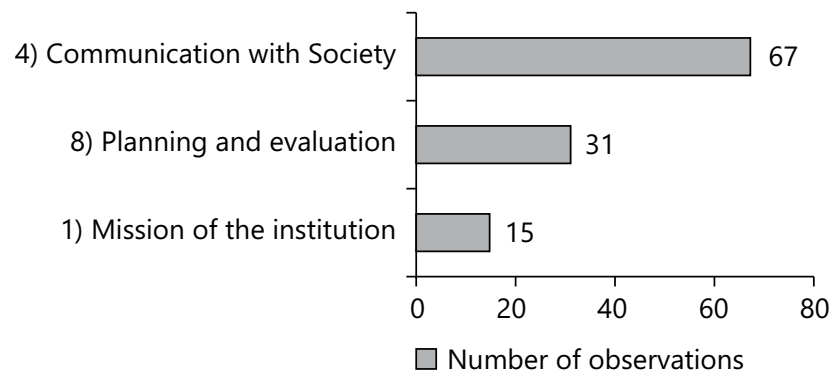

Source: Prepared by the authors (2017)

Regarding Communication with Society, important contributions were presented to circumvent the confirmation about the lack of knowledge of the community about the institution. Among them, the importance of clarifying the mission, vision, values, objectives and purpose of FI. It was suggested publicizing the progress of the IDP actions and establishing policies to promote transparency throughout 
the institution, with special attention to budget and finance. These aspects can be observed in the respondents' statements (R37 and R85).

Although the mission, vision and values of the institution are written in the IDP, an effective action of the institution regarding its dissemination is lacking (R37).

There is no transparency regarding finances and budget in the institute. Plus, the IDP does not define policies in this aspect (R85).

About this dimension, there was a latent urgency to promote integration between the institution, the community and the productive sectors with the goal of understanding their needs and establishing partnerships with public and private entities for technical cooperation and identification of funding sources. According to Souza et al. (2018): "the evaluation of Higher Education cannot be debated alone in Higher Education institutions; it is necessary to involve the whole of society, becoming a tool for autonomy of institutions and all subjects that are part of them."

Referring to the opinions presented by the FI managers, Brandão $(2012$, p. 9) points out that:

Among the multiple meanings of the expression 'public communications', it is possible to find a common point of understanding that is related to a communicative process that is established between the State, government and society in order to inform to the construction of citizenship. It is following this meaning that the concept has been built in Brazil, especially because of the academic area that has directed its thought in this sense.

Regarding Planning and Evaluation, it was highlighted the urgency to create and revise the regulations and the IDP itself in the perspective that the document becomes more effective and reflects the reality in which the IF present themselves and the needs of these institutions. The need to develop an organizational culture that encourages employees to work with an emphasis on planning was mentioned. These aspects can be observed in the respondents' statements (R25 and R95).

The IDP should be culturally disseminated among all hierarchical levels of the Institution, so that this won't become merely a strategic dialogue without operationalization (R25). 
Some indicators need to be reviewed because there is no clarity of what is intended to be achieved. There are problems in defining concepts and goals (R95).

Concerning the need for objectivity and rationality in planning and corroborating the urgency for changes pointed out by FI managers, Zaros and Lima (2009, p. 3) characterized the role of the mission in strategic planning:

The mission of the organization must follow some specifications: clarity, objectivity, possibility and accessibility; the mission must be clear and objective, have its points well defined, should be possible and accessible to all employees of the organization [...].

Regarding dimension $\mathrm{n}^{\mathrm{o}} 1$ "Institutional Mission", the respect to the traditions of the federal public Higher Education network stood out. However, the respondents emphasized the urgency for institutions to always carry out what was planned, trying to balance the Teaching demands with the demands of the administrative area and the management of people, in order to align practices with institutional values. These aspects can be observed in the respondents' statements (R63 and R85).

The IDP is formulated primarily with a focus on teaching, we have little involvement in the administrative sphere and even less in the area of people management (R63).

There is a discrepancy between the goals of the IDP and the practices adopted at the institute (R85).

Respondents' answers were aligned with Kunsch (2003). This author describes the mission as the raison d'être of an organization, expressing its role in society by exposing its purposes and achievements, as well as the services or products offered.

\subsection{Pedagogical and methodological aspects}

Figure 2 presented a summary of the responses related to pedagogical and methodological aspects. Among the three dimensions identified, the main dimension was the $n^{\circ} 5$ "Personnel Policies", with 28 opinions or $57 \%$ of the total answers, followed by dimension $\mathrm{n}^{\circ} 2$ "Policies for teaching, research and extension", with 15 opinions or $31 \%$ of the total opinions and, with a lower number of comments, dimension $\mathrm{n}^{\circ} 7$ "Physical Infrastructure", with 6 opinions or $12 \%$ of total responses. 
Figure 2 - Managers' perceptions of pedagogical and methodological aspects

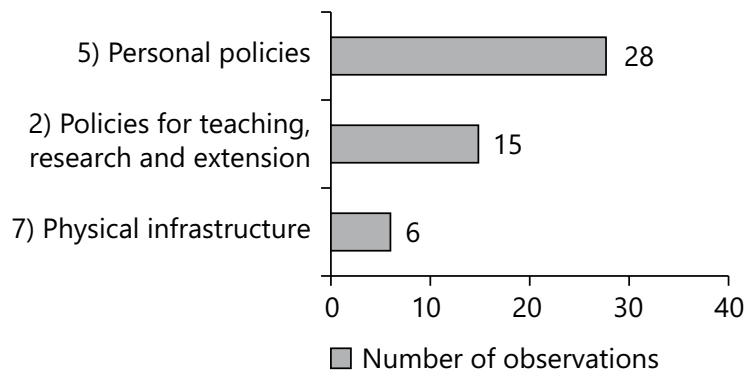

Source: Prepared by the authors (2017)

Regarding the personnel policy, it was evidenced the urgency for professional appreciation that works in the FI, and to do so it was suggested the development of a permanent policy of continuous training of the public servants, with special attention to trainings that consider the performance of the public servant in the areas of the public service. It was emphasized the need for a correct dimensioning of the work force in the institutions, taking as methodological reference, such as Herrera and Cancino (2018), the competency-based management and the knowledge management. These aspects can be observed in the respondents' statements (R04 and R84).

Institutionalizing teaching/technical pedagogical training for newcomers in the institution (R04).

It is necessary to implement the competency-based management, as well as the knowledge management in the institute (R84).

Competency-based management consists of identifying the indispensable competences, including knowledge and skills that impact professional efficiency and effectiveness, as well as pointing out the shortcomings or deficiencies of qualification for special activities or services (CARVALHO, 2013).

According to Terra (2005), knowledge management seeks to organize the main policies, processes and tools of management and technology in light of a better understanding of the processes of generation, identification, validation, dissemination, sharing, protection and use of strategic knowledge to generate results for the institutions and benefits for internal and external collaborators. 
Also on the policy for human resources, it was suggested the implementation of a permanent pedagogical training action aimed at professionals who act directly in Teaching activities. It was pointed out the urgency for the development of public servant training courses for management, thus stimulating the culture of meritocracy for the provision of commissioned positions.

Concerning the policies for teaching, research and extension, in addition to the requests for the improvement of the Institutional Political Project (IPP) of each FI, it was highlighted the urgency to restructure course plans so that they may account for more practical classes in their curricular grades and that these classes can use contemporary learning methods and in accordance with the established in the IDP, being aligned with the concerns of Figueiredo and Salles (2017) regarding the causes of student dropout. These aspects can be observed in the respondents' statements (R09 and R83).

[...] there is a lack of knowledge about the pedagogical aspects that govern an educational institution that is neither a university nor a technical school, but all of them at the same time (R09).

[...] the formation of curriculum of the courses could be discussed with the entities that act in the area, so that it is not academic only, but that they are in agreement with the reality of the community itself (R83).

Also on educational policies, especially those focused on the research axis, the need to establish an institutional policy for the promotion of technological innovation that includes intellectual property, patent recognition and technology transference processes was pointed out.

Per Guimarães (2008, p. 7), his reasoning:

[...] the IPP must express a contemporary worldview and the role of Higher Education in the face of the new globalized and technological conjuncture, while at the same time it should expose, comprehensively, the role of HEI and its social contribution to the local, regional and national levels, through education, research and extension as essential components to the critical training of citizens and future professionals, in the search of the connection between the real and the desirable. 
Regarding physical infrastructure, it was evidenced that, in general, FI have a precarious or inadequate infrastructure, harming the student's Education and, consequently, their employability. It was punctuated the urgency to build a space for the promotion of cultural activities on the campus as well as facilitate integration between the institution and the community.

About this aspect, Vargas $(2015$, p. 9) clarifies that:

[...] the process of Teaching expansion presents structural problems, because the speed in the construction of schools is not accompanied by an adequate infrastructure for better professional formation of these students, due to the absence of equipped laboratories, libraries and the quantity required of teachers and administrative staff.

\subsection{Social and cultural aspects}

Figure 3 presented the grouping of responses related to social and cultural aspects. Among the two identified dimensions, the dimension $\mathrm{n}^{0} 3$ "Social Responsibility" was highlighted, with 36 opinions or $82 \%$ of the total opinions for this aspect, followed by dimension $n^{\circ} 9$ "Student Service Policy", with 8 opinions or $18 \%$ of total answers.

Figure 3 - Managers' perceptions of social and cultural aspects

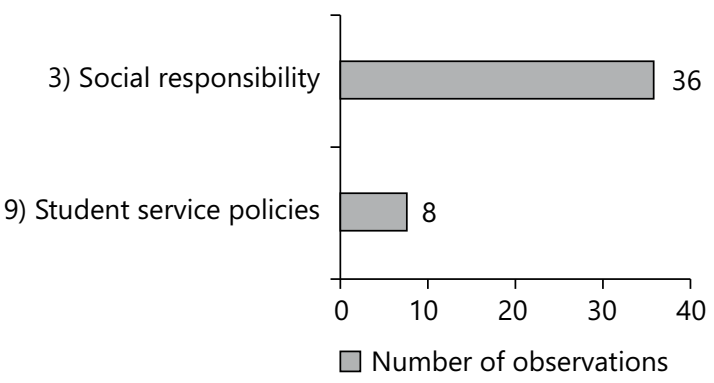

Source: Prepared by the authors (2017)

Concerning social responsibility, the respondents highlighted the urgency to develop institutional actions that deal with diversity, including strengthening regional culture, promotion of gender-sensitive actions and initiatives that tackle ethno-racial issues that contemplate sexuality and sexual orientation, that discuss 
religious diversity and that address diversity in the institution in all its scope. These aspects can be observed from the respondents' statements (R64 and R91).

There are no mentions on the IDP about issues of creed, gender, sexuality, and ethnicity (R64).

The heterogeneity of students and the lack of ability to work with those who have difficulty and are out of school for a long time are limitations, and the Institute has not yet been able to adapt to this reality (R91).

Still on the social responsibility, it was stressed the urgency for institutions to develop actions that combat social inequality, a concern highlighted by Senkevics (2018). The concept of diversity, not reflected in the scope of the IDP of FI, was addressed by Almeida (2008, p. 5). According to the author:

The term diversity, as it has been widely diffused in the field of government policies, has a lot to do with contemporary theories of multiculturalism and refers not only to racial and ethnic issues, but to a series of other social life areas: sexual, religious and cultural diversities (ALMEIDA, 2008, p. 5).

Regarding student assistance policies, it was evidenced the urgency to institutionalize policies to combat school dropout in order to promote student permanence and success. It was pointed out the need to establish partnerships with the productive sectors with the perspective to ensure the insertion of students in the labor market. These aspects were recommended by Prestes and Fialho (2018) and can be observed in the respondents' statements (R62 and R91).

[...] there is no institutional policy of inclusion and anti-drop out for academic success (R62).

[...] a big step is missing, we need more partnerships, more participation of all in the process, so that we can promote the inclusion of students in the labor market (R91).

To Baggi and Lopes (2011) drop out is a problem that is worrying the educational institutions due to its social, academic and economic consequences. The solution or minimization of this problem is complex, requires a systematic monitoring and knowledge of the possible causes for the development of effective intervention strategies (LIMA; MACHADO, 2014). 


\subsection{Legal and administrative aspects}

Figure 4 presented the set of responses related to legal and administrative aspects. Among the two Sinaes dimensions identified in this aspect, the $\mathrm{n}^{\circ} 6$ "Organization and Management of the Institution" had 37 opinions or 82\% of the total answers, followed by dimension 10 "Financial Sustainability", with 8 opinions, corresponding to $18 \%$ of the total responses.

Figure 4 - Perceptions of managers on legal and administrative aspects

6) Organization and management

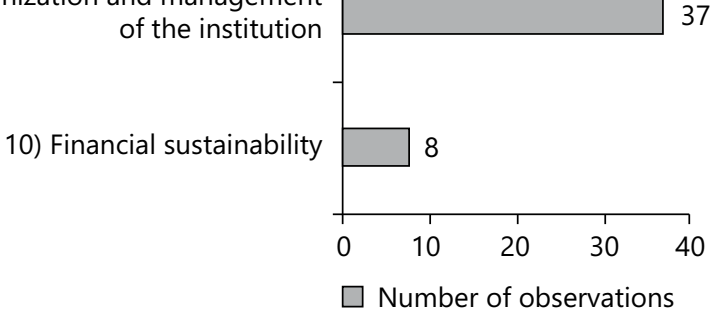

Source: Prepared by the authors (2017)

Regarding the organization and management of the institution, it was emphasized that immediacy, reactivism and discretionary attitudes hinder planning, similar to the results found by Silva and Ferreira (2018). On the other hand, there is an urgency to stimulate actions that reinforce democratic and participatory management by strengthening the internal commissions of the FI, such as the Proper Evaluation Committee (PEC), the Internal Supervisory Committee (ISC), Ethics Committee (ETCO), including to act in an advisory manner for the management of financial issues and personnel sizing.

Still about this dimension, it was pointed out that bureaucracy and the power centralization of processes and budgets hinder the contracting of goods and services and delay the activities of the institution. Such aspects can be observed in the respondents' statements (R62 and R66).

$[\ldots]$ there are no procedure rules, and that opens the way for opinions and interference based on the managers' will, exacerbating his discretionary power (R62). 
[...] there is a difficulty in the operationalization of many actions, given the numerous laws and administrative impediments to allow rapid response to society's demands (R66).

According to Schuch (2007, p. 56), the difficulty of implementing democratic management in FI is mainly due to the unpreparedness of their employees.

The democratic management is a process in constant construction that has in the classroom its embryo, the first opportunity of democratic experience of the student, teacher, parents, management and employees. It is a process that is done on a daily basis in school. No matter how much of it may be laid down in the Law, if there are no people prepared for its exercise, it will not happen in practice (SCHUCH, 2007, p. 56).

Concerning financial sustainability, it was evaluated by the respondents that the budget planning in FI is inefficient; it was shown that the limitations and unexpected budget cuts hinder the implementation of what was planned beforehand. However, to counteract budgetary constraints, it was suggested that FI should seek external funding sources to assist in the implementation of its planning. Such aspects may be observed in the statements of the respondents (R41 and R83).

The lack of resources impedes the realization of many planned actions, attentive to the urgency to optimize management and provide elements that seek to supply the budget funds with technical cooperation actions and institutional partnerships (R41).

The budget planning and finance demands clarification so that people understand the graphs and charts that are displayed (R83).

Regarding the prospect for external financing sources, Corbucci (2004, p. 30) agrees with the opinion of the managers interviewed:

[...] The search for alternative funding sources can be seen as an institutional survival initiative that allows FI to ensure, on different levels and degrees, the maintenance of their technical staff, to fulfill their essential functions and the replacement and/or purchase of equipment. 


\section{Conclusions}

Among the limitations identified by managers, concerning political and institutional aspects, we can highlight the need to improve the institution's communication process with the society, since the concern of managers with the society ignorance was perceived according to the IF.

Another hindrance evidenced by managers was related to social and cultural aspects, since they identified the need for FI to develop permanent policies that include diversity in all their scopes, including actions to identify and strengthen the diversity of the institution.

As for the legal and administrative aspects, it became evident that the FI need to improve their organization and management; as a suggestion, they should strengthen democratic and participatory management and search for external financing sources to overcome the constant budget constraints.

Regarding contributions related to pedagogical and methodological aspects, the most frequent opinion was the urgency for FI to establish a permanent policy of continued training of public servants with special attention to their performance in public service and in their specific areas.

By analyzing the opinions of managers, it can be verified that some of the limitations identified in the IDP stem from the specificities of the FI, since both their target audience and their purpose differ from other HEI in Brazil.

As a suggestion for other research, it is proposed that the IDP is analyzed under different perspectives and methodologies, not only by IF managers, providing an out-of-the-box thinking regarding the preparation of documents that guide FI planning and management. 


\section{Limitações do plano de desenvolvimento institucional dos Institutos Federais de Educação Superior do Brasil}

\section{Resumo}

Os Institutos Federais (IFs) são especializados no ensino profissional e tecnológico em diferentes niveis e modalidades. $O$ instrumento para o planejamento e avaliação nas instituições de Ensino Superior no Brasil é o Plano de Desenvolvimento Institucional (PDI) e o objetivo do trabalho é avaliar as limitações do PDI para os IFs. Para tanto, por meio da aplicação de questionário para os gestores dos IFs, obtiveram-se informações que abordaram as limitações do PDI. As principais limitações estiveram relacionadas aos aspectos politicos e institucionais dos IFs, demonstrado pela preocupação dos seus gestores com o desconhecimento da comunidade do que venha a ser a própria instituição.

Palavras-chave: Planejamento. Gestão. Ensino Superior.

\section{Limitaciones del plan de desarrollo institucional de los Institutos Federales de Educación Superior de Brasil}

\section{Resumen}

Los Institutos Federales (IF) están especializados en la enseñanza profesional y tecnológica en diferentes niveles y modalidades. El instrumento para la planificación y evaluación en las instituciones de Enseñanza Superior en Brasil es el Plan de Desarrollo Institucional (PDI) y el objetivo de este trabajo es evaluar las limitaciones del PDI para las IF. Para ello, a través de la aplicación de un cuestionario para los gestores de los IF, se obtuvieron informaciones que abordaron las limitaciones del PDI. Las principales limitaciones estuvieron relacionadas con los aspectos políticos e institucionales de las IF, demostradas por la preocupación de sus gestores con el desconocimiento de la comunidad de lo que es la propia institución.

Palabras clave: Planificación. Gestión. Educación Universitaria. 


\section{References}

ALMEIDA, N. P. Diversidade na universidade: o BID e as políticas educacionais de inclusão étnico-racial no Brasil. Rio de Janeiro, UFRJ, 2008.

ALMEIDA JUNIOR, V. P. O processo de formação das políticas de avaliação da educação superior no Brasil (1983-1996). Tese (Doutorado em Educação) Faculdade de Educação, Universidade Estadual de Campinas, Campinas, 2004.

ANDRIOLA, W. B.; ARAÚJO, A. C. Uso de indicadores para diagnóstico situacional de Instituições de Ensino Superior. Ensaio: Avaliação e Politicas Públicas em Educação, Rio de Janeiro, v. 26, n. 100, p. 645-663, Jul./Sept. 2018. https://doi.org/10.1590/s0104-40362018002601062

ATHANÁZIO, M. M. Processo de planejamento estratégico em universidade pública: o caso da Universidade Federal do Pará (UFPA). Dissertação (Mestrado em Políticas e Gestão Públicas] - Universidade Federal do Rio Grande do Norte, Natal, 2010.

BAGGI, C. A. S.; LOPES, D. A. Evasão e avaliação institucional no ensino superior: uma discussão bibliográfica. Avaliação: Revista da Avaliação da Educação Superior (Campinas), Sorocaba, v. 16, n. 2, p. 355-374, Jul. 2011. https://doi.org/10.1590/S1414-40772011000200007

BARDIN, L. Analise de conteúdo. São Paulo: Edições 70, 2011.

BISINOTO, C.; ALMEIDA, L. S. Percepções docentes sobre avaliação da qualidade do ensino na Educação Superior. Ensaio: Avaliação e Políticas Públicas em Educação, Rio de Janeiro, v. 25, n. 96, p. 652-674, 2017. https://doi.org/10.1590/s0104-40362017002501176

BRANDÃO, E. P. Conceito de comunicação pública. In: Duarte, J. (org.). Comunicação pública: estado, mercado, sociedade e interesse público. 3. ed. São Paulo: Atlas, 2012. p. 1-33.

BRAZIL. Decreto $\mathrm{n}^{\circ}$ 9.235, de 15 de dezembro de 2017. Dispõe sobre o exercício das funções de regulação, supervisão e avaliação das instituições de educação superior e dos cursos superiores de graduação e de pós-graduação no sistema federal de ensino. Diário Oficial da União, Brasília, DF, 18 Dic. 2017.

BRAZIL. Lei $\mathrm{n}^{\circ}$ 9.131, de 24 de novembro de 1995. Altera dispositivos da Lei no 4.024, de 20 de dezembro de 1961, e dá outras providências. Diário Oficial da União, Brasília, DF, 25 nov. 1995. 
BRAZIL. Lei n ${ }^{\circ} 10.861$, de 14 de abril de 2004. Institui o Sistema Nacional de Avaliação da Educação Superior -SINAES e dá outras providências. Diário Oficial da União, Brasília, DF, 15 abr. 2004.

BRAZIL. Lei n ${ }^{\circ} 11.892$, de 29 de dezembro de 2008. Institui a Rede Federal de Educação Profissional, Científica e Tecnológica, cria os Institutos Federais de Educação, Ciência e Tecnologia, e dá outras providências. Diário Oficial da União, Brasília, DF, 30 dez. 2008.

BRAZIL. Controladoria-Geral da União. Portal da transparência. Available in: http://www.portaltransparencia.gov.br/. Access in: 15 Nov. 2014.

BRITO, M. I. D. L. Implementação do REUNI na UnB (2008 a 2011): limites na ampliação de vagas e redução da evasão. Dissertação (Mestrado Profissional em Educação) - Universidade de Brasília, Brasília, DF, 2013.

CARVALHO, J. G. Programa Mulheres Mil em Arraial do Cabo: extensão e inclusão com base na sustentabilidade. Extramuros, Petrolina, v. 1, n. 2, p. 92-99, Oct. 2013.

COLOMBO, S. S. Gestão educacional: uma nova visão. São Paulo: Artmed, 2004.

CORBUCCI, P. R. Financiamento e democratização do acesso à educação superior no Brasil: da deserção do Estado ao projeto de reforma. Educação \& Sociedade, Campintas, v. 25, n. 88, p. 677-701, Oct. 2004. https://doi.org/10.1590/S0101-73302004000300003

COSTÁBILE, L. T. Desenvolvimento de um plano estratégico em uma instituição de ensino superior. Dissertação (Mestrado em Engenharia Mecânica) - Faculdade de Engenharia Mecânica, Universidade Estadual de Campinas, Campinas, 2007.

CUNHA, C. J. C. A. Planejamento estratégico em universidades. Florianópolis: Universidade Federal de Santa Catarina, 1995.

FALSARELLA, O. M.; JANNUZZI, C. A. S. C. Corporate Strategic Planning and Information \& Communication Technology Planning: a project based approach. Gestão \& Produção, São Carlos, v. 24, n. 3, p. 610-621, Jul./Sept. 2017. https://doi.org/10.1590/0104-530x481-16

FIGUEIREDO, N. G. S.; SALLES, D. M. R. Educação profissional e evasão escolar em contexto: motivos e reflexões. Ensaio: Avaliação e Políticas Públicas em Educação, Rio de Janeiro, v. 25, n. 95, p. 356-392, Apr./Jun. 2017. https://doi.org/10.1590/s0104-40362017002500397 
FISCHMANN, A.; ALMEIDA, M. I. Planejamento estratégico na prática. 2. ed. São Paulo: Atlas, 2009.

FRANGELLA, R. C. P.; MENDES, J. C. B. “O que é o bom resultado?” Indagando o sentido da avaliação e suas articulações curriculares. Ensaio: Avaliação e Políticas Públicas em Educação, Rio de Janeiro, v. 26, n. 99, p. 296-315, Apr./June 2018. https://doi.org/10.1590/s0104-40362018002600982

GUIMARÃES, A. M. P. Canais de Atendimento ao aluno em instituições de ensino particulares na cidade de São Paulo: um estudo exploratório. Dissertação (Mestrado em Hospitalidade) - Faculdade Anhembi Morumbi, São Paulo, 2008.

HERRERA, C. I.; CANCINO, V. E. Asesoramiento a equipos de gestión y liderazgo educativo desde el abordaje de las competencias funcionales. Ensaio: Avaliação e Políticas Públicas em Educação, Rio de Janeiro, v. 26, n. 101, p. 1220-1239, Oct./Dec. 2018. https://doi.org/10.1590/s0104-40362018002601381

\section{INSTITUTO NACIONAL DE ESTUDOS E PESQUISAS EDUCACIONAIS} ANÍSIO TEIXEIRA - INEP. Sinopses estatísticas da educação superior graduação. Available from: http://portal.inep.gov.br/web/guest/sinopses-estatis ticas-da-educacao-superior. Access in: 30 Apr. 2019.

KUNSCH, M. M. K. Planejamento de relações públicas na comunicação integrada. São Paulo: Summus, 2003.

LIMA, E.; MACHADO, L. A evasão discente nos cursos de licenciatura da Universidade Federal de Minas Gerais. Educação Unisinos, São Leopoldov. 18, n. 2, p. 121-129, May/Ago. 2014.

MISSIO, E. F.; ALVES, P. S.; HILDENBRAND, L. O Relatório de Avaliação Institucional da Faculdade de São Lourenço (MG): um estudo meta-avaliativo. Meta: Avaliação, Edição Especial, n. 2, p. 79 - 98, 2018.

MORAES, M. C. B.; KALNIN, G. F. Qualidade na educação superior: uma revisão teórica da evolução conceitual no campo da educação superior. Ensaio: Avaliação e Políticas Públicas em Educação, Rio de Janeiro, v. 26, n. 100, p. 530-551, July/Sept.2018. https://doi.org/10.1590/s0104-40362018002601114

PRESTES, E. M. T.; FIALHO, M. G. D. Evasão na educação superior e gestão institucional: o caso da Universidade Federal da Paraíba. Ensaio: Avaliação e Políticas Públicas em Educação, Rio de Janeiro, v. 26, n. 100, p. 869-889, July/Sept. 2018. https://doi.org/10.1590/s0104-40362018002601104 
SÁ, V. Avaliação institucional de escolas de Educação Básica em Portugal: políticas, processos e práticas. Ensaio: Avaliação e Políticas Públicas em Educação, Rio de Janeiro, v. 26, n. 100, p. 801-821, July/Sept. 2018. https://doi.org/10.1590/s0104-40362018002601163

SCHUCH, C. C. T. Implementação da política da autonomia financeira em duas escolas públicas estaduais do Rio Grande do Sul: um estudo de caso. Dissertação (Mestrado em Educação) - Universidade Federal do Rio Grande do Sul, Porto Alegre, 2007.

SENKEVICS, A. S. Contra o silêncio racial nos dados universitários: desafios e propostas acerca da Lei de Cotas. Educação e Pesquisa, São Paulo, v. 44, p. 1-23, 2018. https://doi.org/10.1590/s1678-4634201844182839

SILVA, R. Balanced Scorecard - BSC: gestão de ensino superior, gestão profissionalizada e qualidade de ensino para instituições de ensino superior privado. Curitiba: Juruá, 2008.

SILVA, L. G. A.; FERREIRA, S. Plano de Desenvolvimento da Educação e Plano de Ações Articuladas: interferências e contradições do Plano de Ações Articuladas na gestão dos sistemas municipais de ensino em Goiás. Ensaio: Avaliação e Políticas Públicas em Educação, Rio de Janeiro, v. 26, n. 100, p. 1108-1127, July/Sept. 2018. https://doi.org/10.1590/s0104-40362018002601200

SOUZA, F. J. et al. Avaliação da Educação Superior no Brasil - do Provão ao ENADE: um estudo meta-avaliativo. Meta: Avaliação, Rio de Janeiro, Edição Especial n. 2, p. 22-42, 2018. https://doi.org/10.22347/2175-2753v10i0.1956

TERRA, J. C. C. Gestão do conhecimento: o grande desafio empresarial. Rio de Janeiro: Campus, 2005.

VARGAS, A. C. L. A política de educação profissional e tecnológica nos anos 2000: novos marcos para a formação da classe trabalhadora. In: COLÓQUIO NACIONAL, 3., 2015. Anais[...] Available from: http://ead.ifrn.edu.br/portal/ wp-content/uploads/2016/02/Artigo-411.pdf. Access in: 2 May 2016.

ZAROS, R. A.; LIMA, S. A. P. Introdução ao planejamento estratégico organizacional. Revista Cientifica Eletrônica de Administração, Garça, v. 9, n. 17, Dec. 2009. 


\section{Information about the authors}

Alexandre Nascimento de Almeida: Doctorate in Forestry. Professor at the Universidade de Brasilia in the Postgraduate Program in Public Management. Contact: alexalmeida@unb.br iD http://orcid.org/0000-0002-9113-0729

Anderson Allan Almeida Galvão: Master in Public Management by Postgraduate Program in Public Management. Server of the Instituto Federal de Brasilia. Contact: 1745190@etfbsb.edu.br

iD http://orcid.org/0000-0002-0079-888X 